\title{
Supporting Collaborative Efforts in Implementing Evidence-Based Reading Interventions: The Role of Online Databases
}

\author{
Gina Coffee \\ Loyola University Chicago, gcoffee@luc.edu \\ Adam S. Kennedy \\ Loyola University Chicago, akenne5@luc.edu \\ Markeda L. Newell \\ Loyola University Chicago, mnewell2@luc.edu
}

Follow this and additional works at: https://ecommons.luc.edu/education_facpubs

Part of the Education Commons

\section{Author Manuscript}

This is a pre-publication author manuscript of the final, published article.

\section{Recommended Citation}

Coffee, Gina; Kennedy, Adam S.; and Newell, Markeda L.. Supporting Collaborative Efforts in Implementing Evidence-Based Reading Interventions: The Role of Online Databases. Journal of Educational and Psychological Consultation, 24, 2: , 2014. Retrieved from Loyola eCommons, Education: School of Education Faculty Publications and Other Works, http://dx.doi.org/10.1080/10474412.2014.903188

This Article is brought to you for free and open access by the Faculty Publications and Other Works by Department at Loyola eCommons. It has been accepted for inclusion in Education: School of Education Faculty Publications and Other Works by an authorized administrator of Loyola eCommons. For more information, please contact ecommons@luc.edu.

\section{(c) $($ () $\ominus$}

This work is licensed under a Creative Commons Attribution-Noncommercial-No Derivative Works 3.0 License. (c) Taylor \& Francis, 2014. 
Running head: SUPPORTING COLLABORATIVE EFFORTS

Supporting Collaborative Efforts in Implementing Evidence-Based Reading Interventions:

The Role of Online Databases

\author{
Gina Coffee \\ Loyola University Chicago \\ Markeda L. Newell \\ University of Wisconsin - Milwaukee \\ Adam S. Kennedy \\ Loyola University Chicago
}

\begin{abstract}
Author note
Gina Coffee, School of Education, Loyola University Chicago; Markeda L. Newell, Department of Educational Psychology, University of Wisconsin - Milwaukee; Adam S. Kennedy, School of Education, Loyola University Chicago.

Correspondence concerning this article should be addressed to Gina Coffee, School of Education, Loyola University Chicago, 820 North Michigan Avenue, Chicago, IL 60611. E-mail: gcoffee@luc.edu
\end{abstract}




\begin{abstract}
The purpose of this article is to provide an explanation of how effective reading interventions are identified. Through a review of the National Reading Panel's general findings, along with a review of systems currently used to evaluate and disseminate specific reading interventions, a discussion of what works in reading is presented. The Evidence-Based Intervention (EBI) Network is presented as a resource for facilitating collaboration across disciplines. Finally, a framework to guide collaborating professionals in the implementation of evidence-based reading interventions is proposed.
\end{abstract}




\section{Supporting Collaborative Efforts in Implementing Evidence-Based Reading Interventions: The Role of Online Databases}

There have been several narrative and quantitative reviews of reading programs and practices in general education, special education, school psychology and related fields (e.g., Berkeley \& Thomas, 2010; Cheetham \& Allor, 2012; NICHD, 2000). Nevertheless, reading remains a significant struggle for many students in the United States. According to the National Assessment of Educational Progress (NAEP, 2010), only 33\% of $4^{\text {th }}$ grade students performed at the proficient level, which means their reading skills are adequate given their grade level. However, most $4^{\text {th }}$ grade students (i.e., 67\%) performed below expectation for their grade level (NAEP). By $8^{\text {th }}$ grade, most students continued to perform below expectation (i.e., $75 \%$ ) in reading. In addition, there are significant gaps in reading performance between White and Black students, English Language Learners and native English speakers, and students with disabilities and students without disabilities (NAEP, 2010). Taken together, these data indicate a gap between the predominance of research that demonstrates the effectiveness of reading programs and instructional practices and the implementation of these research-based practices in schools.

Clearly, there is a significant need to bridge this research-to-practice gap so that more students who struggle with reading can have access to high-quality, evidence-based reading interventions that have a high likelihood of improving their reading performance. However, given that most students are performing below expectation in reading, it will take professionals from multiple disciplines working collaboratively to identify and implement those interventions in schools. One method of identifying suitable evidence-based interventions is to consult organizations with a proclaimed mission of identifying, reviewing, and disseminating reading 
research to educators who can use the information to implement evidence-based interventions with integrity.

\section{Who Determines What Works in Reading?}

The National Reading Panel (NRP) was one of the earliest, nationally organized efforts to identify research-based reading programs and instructional practices that should be implemented in classrooms. The National Institute of Child Health and Human Development (NICHD) established the NRP in 1997 to review research on reading including alphabetics, fluency, comprehension, teacher education, and computer technology (NICHD, 2000). The panel spent over two years reviewing the available data, and they convened open meetings to obtain public input. The panel released a final report titled The Report of the National Reading Panel: Teaching Children to Read on April 13, 2000 (NICHD, 2000).

The findings of the report indicated that developing phonemic awareness, reading fluency, and comprehension are essential components of learning to read. Specifically, the review of evidence suggested that teachers can improve phonemic awareness by providing systematic phonics instruction and explicitly teaching students how to manipulate phonemes. However, the NRP noted that teachers must not only teach phonemic awareness, but they must also teach children how to apply this knowledge to decode, spell, and read. In addition, the NRP suggested teachers provide guided oral reading to improve reading fluency, and, to improve vocabulary, teachers should directly and indirectly teach vocabulary using repetition and multiple exposures. Finally, the NRP made recommendations about teacher education to support reading. In-service professional development was found to improve teacher instruction, and there were no clear findings on the use of instructional technology to improve reading (NICHD, 2000). 
These findings were presented to Congress, have been made available on the organization's websites, and panel members have presented the findings at various conferences and meetings.

Although the final report has been disseminated at several venues, the report has been critiqued. Researchers and educators have identified limitations in the methodology used to gather the data (see Burns, 2003) and the interpretations of the findings (see Hammill \& Swanson, 2006). Specifically, given that the panel's review was a combination of qualitative and quantitative findings, some of their conclusions are difficult to generalize and understand (Burns, 2003). Moreover, the panel only conducted a one-time review of reading research; therefore, the NRP report does not reflect current changes in reading research and findings.

One of the major limitations of the NRP report is that it only focused on reading for school-aged children and did not review research on children birth to 5-years old. Therefore, given the significant influence of the NRP report coupled with the lack of information about the development of early literacy skills, the National Institute for Literacy partnered with the National Center for Family Literacy to convene a research panel entitled National Early Literacy Panel (NELP) in 2002. The purpose of the panel was to synthesize the scientific research on the development of early literacy skills in children birth to five. In order to review research on early literacy, the panel identified important conventional literacy skills (e.g., decoding, oral reading fluency, and comprehension) and then proposed emergent or precursor literacy skills that are most predictive of developing conventional literacy skills (NELP, 2008). Six essential emergent literacy skills were identified: 1) alphabet knowledge, 2) phonological awareness, 3) rapid automatic naming of letters and numbers, 4) rapid automatic naming of objects or colors, 5) writing letters or name, and 6) phonological memory. Once these emergent skills were identified, the panel reviewed research on interventions designed to support their development. Five 
categories of interventions were identified: (1) code-focused interventions (i.e., teaching the correspondence between letters in written words and sounds in spoken words), (2) sharedreading, (3) parent and home programs, (4) preschool and kindergarten programs, and (5) language enhancement interventions (NELP, 2008).

The results of the NELP meta-analysis indicated that all five types of interventions had a significant impact on early literacy skills. Specifically, code-focused interventions were the only category of interventions that measured conventional literacy skills; therefore, these were the only interventions that demonstrated a significant, positive effect on conventional literacy skills. However, the other interventions were also effective in other ways. Specifically, shared-reading interventions significantly improved print knowledge and oral language skills. Parent and home programs also improved oral language skills as well as general cognitive abilities. On the other hand, language enhancement interventions only significantly improved oral language skills while preschool/kindergarten programs improved spelling and reading readiness skills. The reviewers noted that there was not much differentiation between the effective reading instruction in kindergarten and preschool. Taken together, the findings from the NRP and NELP should be viewed on a continuum of supporting the development of effective readers.

The NRP and the NELP are research reports and publications. They provide a scientific basis to assist in understanding; however, they do not easily translate to practice. To address this research-to-practice gap, evidence-based research websites are proliferating. The function of these evidence-based research websites is to condense the research and provide easy-to-use information that can be consumed by educators. New evidence-based research dissemination websites continually emerge and each sponsoring organization has its own criteria for defining high-quality research, as well as its own method of dissemination. Some of the most well-known 
evidence-based research websites include the What Works Clearinghouse (sponsored by Institute for Education Sciences), Center for Data-Driven Reform in Education (sponsored by Institute for Education Sciences), and the Taskforce on Evidence-Based Interventions in School Psychology (sponsored by the Society for the Study of School Psychology and the American Psychological Association Division 16). Although these websites have different sponsors, they share a common purpose of evaluating current educational research, providing a rating for the quality of that research, and then disseminating that research to the public. They also all provide criteria for reviewing reading research and identifying the most effective reading programs and instructional practices. These are only few of the numerous websites that share this purpose, and although the proliferation of these websites is advantageous for building repositories for evidence-based interventions; there are some important limitations as well.

\section{What are the Limitations of Review Efforts?}

Clearly, each of these resources has a focus on identifying and disseminating evidencebased reading research to improve reading performance outcomes in schools. As can be seen in Table 1, they address similar reading topics including alphabetics, fluency, comprehension, curriculum, and instruction. However, the interpretations that can be made about the quality of evidence can be challenging. The WWC and CDDRE base their evidence standards, in part, on the number of published studies and the sample sizes for those studies. Therefore, some interventions may be recognized as having strong evidence while another may identify the same intervention as having weak or limited evidence. This approach can be a double-edged sword in that different reviewers/consumers can come to different conclusions about the quality of the evidence. Given this variability in determining the quality of the evidence, making clear determinations about what works in reading can be a challenge. In addition to the variability in 
evidence ratings, it is of concern that cultural considerations are lacking. The Taskforce on Evidence-Based Interventions in School Psychology suggest that codes to evaluate ecological validity, researcher perspective, participatory nature of the research, cultural characteristics of participants, cultural appropriateness of measures, cultural moderators, and cultural significance of the research (http://www.indiana.edu/ ebi/) are appropriate. Although the other organizations have an interest in obtaining research related to diverse populations, particularly due to the lagging reading performance among minority students, there are no clear evaluation criteria for cultural considerations in the evaluation of the quality and appropriateness of the evidence for diverse populations. The potential problem is the continued development of an evidence-base that cannot clearly demonstrate its effectiveness across groups (see Ingraham \& Oka, 2006). Given the significant gap in reading performance for racial/ethnic minorities, English Language Learners, students from low-income backgrounds, and students with disabilities (NAEP, 2010), there is a tremendous need to conduct multicultural research that makes cultural considerations, analyzes the effectiveness of these cultural considerations, and (at the very least) analyzes group differences in effectiveness for reading programs/practices (see Newell et al., 2010). As Ingraham \& Oka (2006) stated, the issue is not that all interventions will not work with diverse populations. Rather, the issue is that because we have not studied it then we do not know what will or will not work.

\section{Who Are The Consumers?}

The variability in evidence ratings and lack of cultural considerations in research reviews are significant barriers to the identification and dissemination of evidence-based research in reading. However, one of the most glaring issues is the lack of clarity about who are the consumers of evidence-based reviews and how they are systematically receiving these findings 
so that they are included in school-based practices. It is unclear who exactly is able to consume and implement this information so that it is reaching students. General and special education teachers, reading specialist, principals, district- and state-level policymakers, school psychologists have a stake in or at least at interest in improving student reading performance; therefore, any of these professionals may be in a position to seek out evidence-based reading practices. However, this fundamental aspect of dissemination, which is how should this information be organized, presented and packaged for the intended consumer has been neglected as the resources seem designed for educational researchers rather than practitioners. However, it is important to note that the WWC and BEE also produce educator-friendly documents that are available online and may be used to facilitate implementation of practices in schools.

Clearly there is a need for an interdisciplinary approach to the dissemination of evidencebased reading research. It is reasonable that a school psychologist will have trouble translating the evidence-based research on a specific reading instructional strategy because a school psychologist is not a teacher or a reading specialist (Kibby, 2009). Conversely, there may be an evidence-base on reading curriculum or policy that does not require esoteric knowledge about reading, and a school psychologist or administrator can make use of that literature to support teachers in implementing it in the classroom. In both instances, it is essential to consider how professionals can work in an interdisciplinary manner to support each other in consuming and implementing these evidence-based practices. Given the variability in criteria and evidenceratings, it seems likely that various professionals would identify different practices that have some evidence of support. At best, this creates an additional level of complex, collaborative problem-solving for the educators. At worst, it may lead to confusion and disagreement that prevents the implementation of high-quality evidence-based practices in schools (Slavin, 2008), 
thus reinforcing the research-to-practice gap that all of this painstaking work was designed to address. As a result, an interdisciplinary network or system for establishing an evidence-base for reading is greatly needed.

\section{The Evidence-Based Intervention (EBI) Network}

The EBI Network represents a collaborative effort between School Psychology training programs at the University of Missouri, Indiana University, and East Carolina University, as well as the Special Education program at the University of Missouri, and is one example of an interdisciplinary educational platform that can facilitate support for struggling readers (EBI Network, 2013). In particular, the EBI Network is a website that integrates information about what works in reading and may function as a framework for interdisciplinary collaboration across educational professionals involved in selecting, implementing, and evaluating reading interventions. The website was developed in 2007 as a resource for the selection of EBIs, and later was enhanced by the addition of videos demonstrating academic and behavioral EBI implementation and resources specific to Response to Intervention, English Language Learners, and foundations of problem solving. Although its primary goal is similar to the previously described online resources, the EBI Network goes a step further by attempting to directly address the needs of school-based practitioners.

A particularly unique feature of the EBI Network that is likely to appeal to educational professionals is its "common problems" framework, whereby interventions presented on the site are meant to address the function of a child's behavior. The common reasons children exhibit academic problems include: (a) the academic activity is too hard, (b) they have not spent enough time doing it, (c) they have not had enough help to do it, (d) they have demonstrated the skill before but are having difficulty applying the skill in a new way, and (e) they do not want to do it 
(Daly \& Martens, 1997). Common reasons children engage in problematic behaviors include: (a) they have not learned the behavior, (b) appropriate behavior is positive reinforced, (c) appropriate behavior results in loss of desired activity, (d) inappropriate behavior removes them from what they do not want to do, (e) inappropriate behavior is positively reinforced, and (f) they have demonstrated the skill before, but are having difficulty applying the skill in a new manner.

The EBI Network is organized in two ways. First, general background information about the site's development, its common problems framework, and EBIs is provided. Following this general introduction to the website, users have access to EBIs for academic and behavior problems organized around the aforementioned common problems framework. For example, with regard to academic interventions, if the user chooses the "The student does not want to do the academic task" option, three relevant interventions are presented: Classwide Antecedent Modifications, Interspersing Easier Problems in Drill Practices, and Mystery Motivator. Each intervention is thoroughly described in a full intervention brief and also demonstrated in videos. As appropriate or available, the evidence supporting each intervention is then presented in an evidence brief.

With regard to reading, almost all of the academic interventions presented on the EBI Network are useful for students with reading difficulties. For example, the interventions offered for students who have the common problem of not having completed the specified academic task before in a particular manner can be applied to difficulties in any academic subject, including reading. In addition, the EBI Network offers interventions specific to reading for students who have not spent enough time doing the academic activity including the HELPS program, Repeated Readings, Incremental Rehearsal, and Partner Reading. Specific to reading, the EBI Network also presents Guided Reading, Story Detective, and Error Monitoring Strategies. 
One of the primary strengths of the EBI Network as a platform for collaboration among educational professionals is its focus on academic and behavioral EBIs that can be easily accessed and implemented in the classroom with few additional resources or materials. Ideally, problem-solving teams could use this site as they develop plans to meet the needs of struggling readers. In addition, the common problems framework of the EBI Network encourages educators to expand traditional views of academic difficulties to view academic problems, in general, and reading problems, in particular, from a functional perspective. For example, within a traditional framework, all reading fluency difficulties may be automatically addressed using a standard protocol such as repeated readings, an evidence-based reading intervention. However, from a functional perspective consistent with the EBI Network, a repeated readings intervention would only be implemented if it is determined the reading fluency difficulties are due to the insufficient time spent reading. However, if it is determined reading fluency difficulties are due to lack of student motivation, an intervention designed to enhance motivation would be implemented instead.

Collaboration may be enhanced on the EBI Network via applications such as a message board and an electronic mailing list that may result in collaborating across schools and ultimately result in the development of an online community for educational professionals.

\section{How Can We Facilitate Collaboration?}

The implementation of reading interventions is unlikely to be achieved by any one individual, and all educational professionals are indeed accountable for improving student performance and influencing school success. Whether reading interventions are planned and implemented by problem-solving teams or through consultative teams, teams must work collaboratively to ensure selected instruction methods and interventions are evidence-based and 
promote the progress of children with diverse needs (Friend \& Cook, 2012; Idol, Nevin, \& Paolucci-Whitcomb, 2000; Murawski \& Hughes, 2009).

In order to make optimal use of evidence-based intervention resources, one must first determine where and how they fit into existing intervention delivery systems. Certainly, resources such as those described in the preceding sections vary in terms of their user friendliness, comprehensiveness, and comprehensibility, as well as the amount of work involved in translating their recommendations into practice. However, their utility is not limited to the process of intervention selection; they may be of value during other phases of collaborative consultation as well, so they must be carefully considered and evaluated with these broader processes in mind.

As described by Burns, Wiley, and Viglietta (2008), the process of problem-solving should involve collaboration and shared responsibility during each of four stages: (a) initial consultation, during which student difficulties are behaviorally defined and initial data is collected (reading interventions are also 'brainstormed' during this phase); (b) the problemsolving team conference, where data analysis is performed, reading interventions are again brainstormed, and implementation roles are delegated; (c) follow-up consultation, which involves planning to ensure intervention integrity and additional problem-solving; and (d) a follow-up conference, at which time the process is summatively evaluated in relation to the student's reading needs and new interventions are identified. Reviews of evidence -based reading interventions are potentially quite useful during the initial consultation and problem-solving team conference phases here, with the behavioral definition of reading problems on the EBI Network website representing a key area of alignment between problem-solving model and intervention resource. 
Kratochwill (2008) presented problem-solving consultation through the lens of collaboration as well, identifying four stages to the development of effective problem-solving consultative teams. In the first stage (Establishing Relationships), competence in identifying and planning to address learning and behavioral problems is emphasized within a context of the development of a healthy and positive professional relationship between consultant(s) and classroom teachers. This stage involves laying the groundwork for the remaining stages by addressing skill deficits and resistance proactively. Professional development may decrease resistance and increase the likelihood of successful implementation with fidelity.

The second phase of this model (Problem Identification) involves collaboratively operationalizing student problems and selecting goals for the consultative relationship and can utilize a variety of tools and models for accomplishing this. Problem analysis serves as the third phase of this approach and includes analysis of baseline data, assessing the context within which student goals are addressed, and 'generating broad strategies' (e.g., professional development) that will aid implementation. The fourth phase (Plan Implementation) includes selecting and implementing evidence-based interventions which address students' needs and are consistent with key features of the environment(s) within which they will be implemented. Consultants are invaluable to monitoring plan implementation and providing supports where needed during this phase. In the final phase, the team's plan is evaluated in order to determine overall effectiveness and plans for the future (e.g., skill generalization, ongoing monitoring).

With respect to Kratochwill's model, a resource like the EBI Network demonstration videos could prove useful as a professional development resource once such needs have been identified in the 'establishing relationships' phase. During the next phase, problem 
operationalization could involve behaviorally defining reading problems, thus producing another point of alignment with the EBI Network resources. Finally, the selection of evidence-based interventions in phase four could involve accessing any or all of the online reading/literacy intervention resources presented in Table 1 to determine which reading interventions have a strong evidence-base and which of those evidence-based reading interventions might best meet the needs of a struggling reader or group of readers. Specific applications of the Burns et al. (2008) and Kratochwill (2008) models of collaboration, as well as the evidence-based intervention resources, across problem solving steps are presented in Table 2.

\section{Implications for Consultation and Collaboration in the Field}

Evaluating reading interventions in order to assess their evidence-base, suitability, likelihood of implementation, and appropriateness in a given situation, requires parallel processes of ensuring an intervention's evidence base and its likelihood of successfully meeting local needs. Both of these processes are potentially challenging and time-consuming, with varied guidelines available on which teams may rely. Compounded by the diverse roles of educational professionals who may influence intervention planning and implementation for struggling readers, a model of interdisciplinary collaboration that can be embedded into a school's existing consultation model is critical.

In addition to the aforementioned educational models of collaborative consultation (Burns et al., 2008; Friend \& Cook, 2012; Idol et al., 2000; Kratochwill, 2008), Bronstein (2003) developed a model of interdisciplinary collaboration for social workers to support their work with professionals from other disciplines such as education, healthcare, and mental health in collaboratively meeting the needs of their clients. Given the aforementioned interdisciplinary 
nature of working with struggling readers, it logically follows that this model may also be applied to the multiple professionals collaborating to address the needs of struggling readers.

The components of Bronstein's interdisciplinary collaboration model include interdependence, newly created professional activities, flexibility, collective ownership of goals, and reflection on process. Interdependence refers to each professional's individual engagement in goal-oriented activities, as well as reliance on others' activities in meeting established goals. In the case of a struggling reader, for example, a reading specialist, classroom teacher, and school psychologist might work interdependently when they select an appropriate reading intervention together, the reading specialist individually implements the intervention with the child, the classroom teacher builds in opportunities for maintenance and generalization of the student's new reading skills within the classroom, and the school psychologist monitors the student's progress and evaluates the intervention's effectiveness. In this way, each educator's expertise is highlighted, the tasks are clearly delineated, and all must work together to meet the goal of improving the student's reading outcomes.

The newly created professional activities component of the model builds on interdependence and refers to collaborative acts, programs, or structures that employ and expand each professional's skill set to accomplish goals in a way that may not be possible simply by each individual's contribution. The implementation of multi-tiered, problem-solving models to address children's reading needs is an example of this in the school setting. Specifically, although evaluation efforts have traditionally been the role of the school psychologist, the incorporation of multi-tiered, problem-solving models in schools has expanded the roles of teachers, reading specialists, and administrators to also collect reading data and evaluate intervention effectiveness. 
Bronstein (2003) describes flexibility, the model's next component, as "the deliberate occurrence of role-blurring" (p. 300). This does not mean reading specialists take on the role of administrators, for example; however, whereas an administrator might typically be responsible for selecting and purchasing reading curriculum, a reading specialist may be called upon to inform the administrator's decision. Similarly, although teachers and reading specialists are typically responsible for teaching reading, school psychologists may also implement interventions.

Collective ownership of goals simply refers to the shared responsibility for meeting the team's goals. Among educational professionals, it might mean the aforementioned teacher, reading specialist, and school psychologist not only take responsibility for each of their respective tasks (i.e., intervention implementation, facilitating maintenance and generalization, and progress monitoring and evaluation), but also provide support for one another in completing those tasks. This may be accomplished via structured opportunities for communication, consideration of schedules, and added support in task completion, as needed.

Finally, Bronstein's (2003) model concludes with a reflection on process component whereby collaborating professionals think and talk about the process of working together. Although reflection may occur informally, it might be more productive for teams of educational professionals who work with struggling readers to designate specific times to meet and reflect upon their work together.

Taken together, then, it becomes evident that determining what works in reading is more complicated than an educator independently perusing intervention resources, implementing the intervention, and evaluating its effectiveness. Sites such as the EBI Network certainly provide a starting point for collaborating educational professionals in intervention selection and 
implementation, as it compiles evidence gathered from organizations such as What Works Clearinghouse to share interventions suitable for use in classrooms. Given the interdisciplinary nature of supporting struggling readers, it then becomes important to also understand consultation practices. Finally, taking collaboration one step further with a model of interdisciplinary collaboration to cogently bring together educational professionals with varied roles may enhance reading outcomes for children and provide a structure for utilizing the expertise of all educators. 


\section{References}

Bartholomew, L.K., Parcel, G.S., \& Kok, G. (1998). Intervention mapping: A process for developing theory- and evidence-based health education programs. Health education \& behavior : The official publication of the Society for Public Health Education, 25(5), $545-63$

Bronstein, L. (2003). A model for interdisciplinary collaboration. Social Work, 48(3), 297-306.

Burns, M.K. (2003). Reexamining data from the National Reading Panel's meta-analysis: Implications for school psychology. Psychology in the Schools, 40(6), 605-612.

Burns, M.K. (2007). Reading at the instructional level with children identified as learning disabled: Potential implications for response-to-intervention. School Psychology Quarterly, 22(3), 297-313.

Burns, M.K., Wiley, H.I., \& Viglietta, E. (2008). Best practices in implementing effective problem-solving teams. In Thomas, A., \& Grimes, J. (Eds.), Best practices in school psychology, volume V., pgs. 1673-1688, Bethesda, MD: NASP.

Center for Data-Driven Reform in Education. (n.d.). Best Evidence Encyclopedia. Retrieved from http://www.bestevidence.org/aboutbee.htm

Daly, E. J., \& Martens, B.K. (1997). Model for conducting a functional analysis of academic performance problems. School Psychology Review, 26(4), 554.

EBI Network. (2013). Evidence based intervention network. Retrieved from http://ebi.missouri.edu

Erchul, W.P. (1999). Two steps forward, one step back: Collaboration in school-based consultation. Journal of School Psychology, 37(2), 191-203.

Friend, M., \& Cook, L. (2012). Interactions: Collaboration skills for school professionals $\left(7^{\text {th }}\right.$ 
ed.). Pearson.

Hammill, D.D. \& Swanson, H.L. (2006). The National Reading Panel's meta-analysis of phonics instruction: Another point of view. The Elementary School Journal, 107(1), 1726.

Idol, L., Nevin, A., \& Paolucci-Whitcomb, P. (2000). Collaborative consultation ( $3^{\text {rd }}$ ed.). PROED, Incorporated.

Ingraham, C.L., \& Oka, E.R. (2006). Multicultural issues in evidence-based interventions. Journal of Applied School Psychology, 22(2), 127-149.

Kratochwill, T.R. (1991). Defining constructs in consultation research: An important agenda in the 1990s. Journal of Educational and Psychological Consultation, 2, 291-294.

Kratochwill, T.R. (2008). Best practices in school-based problem-solving consultation: Applications in prevention and intervention systems. In Thomas, A., \& Grimes, J. (Eds.), Best practices in school psychology, volume V., pgs. 1673-1688, Bethesda, MD: NASP.

Kratochwill, T.R., \& Steele, S.E. (2003). Evidence-based practice: Promoting evidence-based interventions in school psychology. School Psychology Quarterly, 18(4), 389-408.

Mahdavi, J.N., \& Beebe-Frankenberger, M.E. (2009). Pioneering RTI systems that work. Teaching Exceptional Children, 42(2), 64-72.

National Center for Education Statistics (2009). The Nation's Report Card: Reading 2009 (NCES 2010-458). Institute of Education Sciences, U.S. Department of Education, Washington, D.C.

National Early Literacy Panel. (2008). Developing early literacy: Report of the National Early Literacy Panel. Executive Summary. Washington, DC: National Institute for Literacy. Newell, M.L., Nastasi, B.K., Hatzichristou, C., Jones, J.M., Schanding, G.R., \& Yetter, 
G. (2010). Evidence on multicultural training in school psychology: Recommendations for future directions. School Psychology Quarterly, 25(4), 249-278.

Slavin, R. (2008). What works? Issues in synthesizing educational program evaluations. Educational Researcher, 37(1), pp. 5-14.

Slavin, R.E., Lake, C., Chambers, B., Cheung, A., \& Davis, S. (2009). Effective beginning reading programs: A best-evidence synthesis. Best Evidence Encyclopedia (BEE): Empowering Education with Evidence on Proven Programs. Johns Hopkins University School of Education's Center for Data-Driven Reform in Education (CDDRE).

Stoiber, K.C., \& Kratochwill, T.R. (2000). Empirically supported interventions and school psychology: Rationale and methodological issues, part I. School Psychology Quarterly, 15(1), 75-105.

Taskforce on Evidence-Based Interventions in School Psychology. (n.d.). Procedural and Coding Manual for Review of Evidence-Based Interventions (2nd ed.). Retrieved from http://www.indiana.edu/ ebi/EBI-Manual.pdf

U.S. Department of Health and Human Services, National Institute of Child Health and Human Development. (2003). Teaching children to read: An evidence-based assessment of the scientific research literature on reading and its implications for reading instruction (NIH Pub. No. 00-4769). Retrieved from http://www.nichd.nih.gov/publications/nrp/smallbook.cfm

What Works Clearinghouse. (2008). WWC Procedures and Standards Handbook. Retrieved from http://ies.ed.gov/ncee/wwc/pdf/wwc_procedures_v2_standards_handbook.pdf 
Table 1

Review of Evidence-Based Intervention Dissemination Organizations

\begin{tabular}{|c|c|c|c|c|}
\hline Organization & $\begin{array}{c}\text { Type of Reading Interventions } \\
\text { Reviewed }\end{array}$ & Scope of Interventions & Resources Provided & Limitations \\
\hline $\begin{array}{c}\text { What Works } \\
\text { Clearinghouse } \\
\text { (WWC) }\end{array}$ & $\begin{array}{l}\text { - Alphabetics } \\
\text { - Fluency } \\
\text { - Comprehension } \\
\text { - Reading Achievement } \\
\text { - Print Knowledge } \\
\text { - Early reading/writing } \\
\text { skills }\end{array}$ & $\begin{array}{l}\text { - } \mathrm{K}-12^{\text {th }} \text { grades } \\
\text { - All populations } \\
\text { including English } \\
\text { Language Learners } \\
\text { and Students with } \\
\text { Disabilities }\end{array}$ & 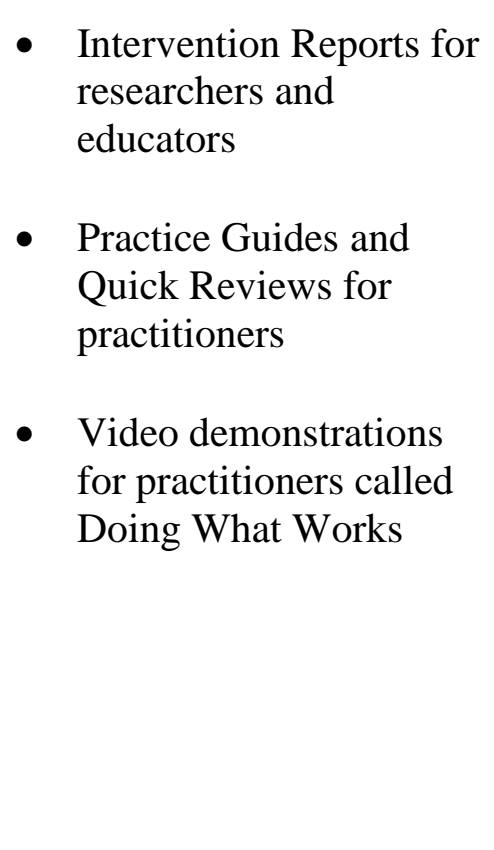 & $\begin{array}{l}\text { The focus on experimental } \\
\text { designs may marginalize } \\
\text { studies that take contextual } \\
\text { factors into account (e.g., } \\
\text { qualitative designs) } \\
\text { - Reviews of the quality of } \\
\text { evidence is based on } \\
\text { number of published } \\
\text { studies and sample size; } \\
\text { therefore, important studies } \\
\text { for which there are a } \\
\text { limited number may not be } \\
\text { recognized by WWC } \\
\text { No inclusion of cultural } \\
\text { validity in the reviews }\end{array}$ \\
\hline $\begin{array}{l}\text { Johns Hopkins University } \\
\text { School of Education's } \\
\text { Center for Data-Driven } \\
\text { Reform in Education: Best } \\
\text { Evidence Encyclopedia } \\
\text { (BEE) }\end{array}$ & $\begin{array}{l}\text { - } \text { Reading Curriculum } \\
\text { - Instructional Technology } \\
\text { - Instructional Processes } \\
\text { - Combined Curriculum }\end{array}$ & $\begin{array}{l}\text { - } \mathrm{K}-12 \text { grades } \\
\text { - All populations } \\
\text { including English } \\
\text { Language Learners } \\
\text { and Students with } \\
\text { Disabilities }\end{array}$ & $\begin{array}{l}\text { - Best Evidence } \\
\text { Encyclopedia for } \\
\text { researchers and } \\
\text { educators } \\
\text { - Better: Evidence-Based } \\
\text { Education Magazine }\end{array}$ & $\begin{array}{l}\text { The focus on experimental } \\
\text { designs may marginalize } \\
\text { studies that take contextual } \\
\text { factors into account (e.g., } \\
\text { qualitative designs) } \\
\text { - Reviews of the quality of }\end{array}$ \\
\hline
\end{tabular}




\begin{tabular}{|c|c|c|c|c|}
\hline & - Instructional Approaches & & (online) for practitioners & $\begin{array}{l}\text { evidence is based on } \\
\text { number of published } \\
\text { studies and sample size; } \\
\text { therefore, important studies } \\
\text { for which there are a } \\
\text { limited number may not be } \\
\text { recognized by CCDRE } \\
\text { - No inclusion of cultural } \\
\text { validity in their reviews }\end{array}$ \\
\hline $\begin{array}{c}\text { The Taskforce on } \\
\text { Evidence-Based } \\
\text { Interventions in School } \\
\text { Psychology }\end{array}$ & $\begin{array}{l}\text { - } \text { Linguistic Awareness } \\
\text { Accuracy of Word } \\
\text { Reading } \\
\text { - Automaticity of Single } \\
\text { Word Recognition and } \\
\text { Fluency of Oral Reading } \\
\text { of Text } \\
\text { - Reading Comprehension }\end{array}$ & $\begin{array}{l}\mathrm{K}-12^{\text {th }} \text { grades } \\
\text { Primary focus is on } \\
\text { prevention and } \\
\text { intervention } \\
\text { programs for } \\
\text { students with } \\
\text { disabilities or } \\
\text { students at-risk }\end{array}$ & - No resources available & $\begin{array}{l}\text { The focus on experimental } \\
\text { designs may marginalize } \\
\text { studies that take contextual } \\
\text { factors into account (e.g., } \\
\text { qualitative designs) } \\
\text { - Consumer determines the } \\
\text { quality of the evidence for } \\
\text { individual studies } \\
\text { Anyone can use the } \\
\text { protocol to rate evidence } \\
\text { and there is no systematic } \\
\text { process for who reviews } \\
\text { research and how that } \\
\text { information is } \\
\text { disseminated } \\
\text { Evidence ratings for } \\
\text { research reviews are not } \\
\text { available via the website or }\end{array}$ \\
\hline
\end{tabular}




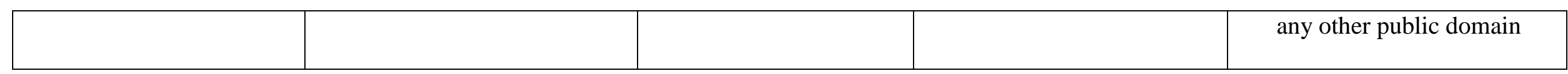


Table 2

The Role of Evidence-Based Intervention Resources in Collaborative Problem-Solving

\begin{tabular}{|c|c|c|c|c|}
\hline & \multicolumn{4}{|c|}{ Common collaborative problem-solving steps } \\
\hline & $\begin{array}{l}\text { Consensus building and } \\
\text { nurturing collaboration }\end{array}$ & $\begin{array}{l}\text { Active problem-solving } \\
\text { activities; collaborative } \\
\text { planning and decision-making }\end{array}$ & $\begin{array}{l}\text { Intervention delivery to } \\
\text { students }\end{array}$ & $\begin{array}{l}\text { Summative assessment } \\
\text { and reflection }\end{array}$ \\
\hline $\begin{array}{l}\text { Collaborative } \\
\text { models }\end{array}$ & $\begin{array}{l}\text { Bronstein (2003): } \\
\text { interdependence } \\
\text { Burns et al. (2008): } \\
\text { collaboration and shared } \\
\text { responsibility } \\
\text { Kratochwill (2008): } \\
\text { establishing } \\
\text { relationships }\end{array}$ & $\begin{array}{l}\text { Bronstein (2003): newly } \\
\text { created professional activities; } \\
\text { collective ownership of goals; } \\
\text { flexibility } \\
\text { Burns et al. (2008): initial } \\
\text { consultation } \\
\text { Kratochwill (2008): problem } \\
\text { identification and analysis }\end{array}$ & $\begin{array}{l}\text { Bronstein (2003): newly } \\
\text { created professional } \\
\text { activities; collective } \\
\text { ownership of goals; } \\
\text { flexibility } \\
\text { Burns et al. (2008): } \\
\text { follow-up consultation, } \\
\text { Kratochwill (2008) plan } \\
\text { implementation }\end{array}$ & $\begin{array}{l}\text { Bronstein (2003): } \\
\text { Reflection on process } \\
\text { Burns et al. (2008): } \\
\text { follow-up conference }\end{array}$ \\
\hline $\begin{array}{l}\text { Roles for } \\
\text { classroom } \\
\text { consultants and } \\
\text { team members }\end{array}$ & $\begin{array}{l}\text { Build relationships } \\
\text { among problem-solving } \\
\text { team members. Identify } \\
\text { and support professional } \\
\text { development needs }\end{array}$ & $\begin{array}{l}\text { Behaviorally define reading } \\
\text { difficulties } \\
\text { Manage/assist baseline data } \\
\text { collection } \\
\text { Identify reading interventions } \\
\text { and classroom strategies } \\
\text { Select goals for the } \\
\text { consultative relationship and } \\
\text { the student. }\end{array}$ & $\begin{array}{l}\text { Ensure intervention } \\
\text { integrity } \\
\text { Select and implement } \\
\text { evidence-based reading } \\
\text { interventions } \\
\text { Monitor implementation } \\
\text { Provide supports where } \\
\text { needed. }\end{array}$ & $\begin{array}{l}\text { Summative evaluation of } \\
\text { student reading progress } \\
\text { and needs } \\
\text { Identify new } \\
\text { interventions } \\
\text { in relation to the } \\
\text { student's reading needs }\end{array}$ \\
\hline $\begin{array}{l}\text { Suggestions for } \\
\text { utilizing evidence } \\
\text { based } \\
\text { intervention } \\
\text { resources }\end{array}$ & $\begin{array}{l}\text { Review interventions } \\
\text { with the goal of } \\
\text { identifying needed roles } \\
\text { and expertise. Evaluate } \\
\text { collaborative team } \\
\text { strengths and needs in } \\
\text { light of these roles and }\end{array}$ & $\begin{array}{l}\text { Use quality of evidence and } \\
\text { intervention selection } \\
\text { guidelines to identify } \\
\text { evidence-based interventions } \\
\text { which address key areas of } \\
\text { student reading difficulty. } \\
\text { Utilize team meeting resources }\end{array}$ & $\begin{array}{l}\text { Review research design } \\
\text { features (including } \\
\text { treatment integrity) and } \\
\text { video models in order to } \\
\text { assess and adjust } \\
\text { practices to maintain } \\
\text { intervention integrity. }\end{array}$ & $\begin{array}{l}\text { Review progress, sharing } \\
\text { data via team meeting } \\
\text { resources. Compare } \\
\text { resources with respect to } \\
\text { local needs and student } \\
\text { diversity. Identify new } \\
\text { interventions as needed. }\end{array}$ \\
\hline
\end{tabular}




\begin{tabular}{|l|l|l|l|l|}
\hline & $\begin{array}{l}\text { identify professional } \\
\text { development goals. }\end{array}$ & $\begin{array}{l}\text { to assist in identifying } \\
\text { appropriate behaviors to target } \\
\text { and progress monitoring } \\
\text { measures. }\end{array}$ & & \\
\hline
\end{tabular}

